\title{
Creating Antibacterial Properties in Flowable Dental Composites by Incorporation of 3,4-dihydropyrimidin-2(1H)- ones
}

\author{
Mehdi Abaszadeh'1(D), Iman Mohammadzadeh²(1)
}

'Pharmaceutics Research Center, Institute of Neuropharmacology, Kerman University of Medical Sciences, Kerman, Iran.

${ }^{2}$ Oral and Dental Disease Research Center, Kerman University of Medical Sciences, Kerman, Iran.

Correspondence: Iman Mohammadzadeh, Oral and Dental Disease Research Center, Kerman University of Medical Sciences, Kerman 76188, Iran. E-mail: iman.mz@gmail.com

Academic Editor: Yuri Wanderley Cavalcanti

Received: 05 April 2020 / Review: 30 November 2020 / Accepted: 20 January 2021

\begin{abstract}
How to cite: Abaszadeh M, Mohammadzadeh I. Creating antibacterial properties in flowable dental composites by incorporation of 3,4-dihydropyrimidin-2(1H)-ones. Pesqui Bras Odontopediatria Clín Integr. 2021; $21:$ e0069. https://doi.org/10.1590/pboci.2021.088
\end{abstract}

\begin{abstract}
Objective: To investigate the antibacterial, mechanical, physical properties and water sorption of flowable dental composites containing 3,4-dihydropyrimidin-2(1H)-ones. Material and Methods: 3,4dihydropyrimidin- $2(1 \mathrm{H})$-ones was synthesized and the antibacterial activity of flowable dental composites containing $0-5$ wt\% 3,4-dihydropyrimidin-2 $(1 \mathrm{H})$-ones and also of their mechanical and physical properties on flowable dental composites were investigated. Flexural strength was measured by a three-point bending test. Compressive strength (CS), Water sorption (WS) and depth of cure (DOC) were investigated. The data were analyzed by One-way ANOVA test. The level of significance was determined as $\mathrm{p}<0.01$. Results: The direct contact test demonstrates that by increasing the 3,4-dihydropyrimidin- $2(1 \mathrm{H})$-ones content, the bacterial growth is significantly diminished $(\mathrm{p}<0.001)$. The average flexural strength results show that with increasing 3,4-dihydropyrimidin-2(1H)-ones until $3 \%$ in the composite, no significant difference was observed in flexural strength $(\mathrm{p}>0.001)$ and the mean of compressive strength results show no significant difference between $0-4 \%$ groups $(\mathrm{p}>0.001)$. The mean of water sorption and depth of cure results shows no significant difference between groups ( $\mathrm{p}>0.001)$. Conclusion: Incorporation of 3,4-dihydropyrimidin-2(1H)ones into flowable resin composites in $3 \%$ wt can reduce the activity of Streptococcus mutans.
\end{abstract}

Keywords: Microbial Sensitivity Tests; Compressive Strength; Streptococcus mutans; Composite Resins. 


\section{Introduction}

Dental caries is a complex disease in which there are interactions between the tooth structure, oral microbial biofilm organized on the tooth surface, dietary sugars, and, to a lesser extent, starches and salivary and genetic influences. Biofilm bacteria metabolize sugars and produce acids that, overtime, demineralizes tooth enamel and can lead to progressive destruction of the tooth's hard tissues - and if left untreated, pain, abscess, and possible tooth loss. The central role of the interaction between dietary sugars and dental biofilm is well established. However, views on the role of specific organisms, such as Streptococcus mutans, in caries causation have changed over time.

Recently, dental composites have been extensively developed due to its advantages, such as natural tooth color and ease of use over conventional materials [1]. According to previous in vitro [2-5] and in vivo $[2,6]$ studies, the accumulation of bacteria and biofilm compared to other dental materials is more on the surface of dental composites, so due to the lack of antibacterial activity, these accumulations cause Secondary caries because polymerization shrinkage causes a gap between the composite resin and the tooth edge which leads to bacterial invasion. This phenomenon decreases tooth restoration longevity and eventually makes the restoration of replacement necessary $[7,8]$. Therefore, more recent studies are focused on the preparation of dental composites with antibacterial characteristics to prevent the occurrence of this type of secondary caries $[9,10]$.

One of the methods to achieve dental composites with anti-bacterial characteristics is to use antibacterial agents in the polymer matrix. Antibacterial components will slowly release from the matrix and prevent bacterial growth. An example of this kind of material is chlorhexidine and fluoride [11-14]. Despite having strong antibacterial activity, they lack the proper prolonged drug release [15]. Another method is to use metal oxides for increasing the antibacterial activity of dental materials [16-18]. But using these oxides in dental materials is limited because most of them will change the color of the tooth [19]. Streptococcus mutans is one of the most effective bacteria in tooth decay [20-24]. For this purpose, various antimicrobial agents have been added to the resins of the composites. Fluoride and chlorhexidine are the most common antimicrobial agents added to the resins. Although these materials had a strong effect at first, their release did not last long and the resin bond strength of composites containing these materials was significantly reduced [25].

Heterocyclic compounds are a group of organic compounds that have been studied widely because of their biological activities, such as antibacterial properties [26-28]. They are the most important member of compounds that are used in pharmacological industries [29,30]. Pyrimidines are a class of aromatic heterocyclic compounds with some useful characteristics, such as antibacterial properties [31,32]. 3,4dihydropyrimidin-2 $(1 \mathrm{H})$-ones are a class of pyrimidines that have many synthesis methods [33]. In continuing our interest in improving dental composites [34-36], in this study, it was synthesized 3,4dihydropyrimidin-2(1H)-ones. The color of this compound is similar to the tooth color [37] that preserves good tooth appearance and was used this compound to provide antibacterial properties in dental material and eventually investigated its effect on mechanical properties, depth of cure and water sorption of flowable dental composites.

\section{Material and Methods}

Ethical Clearance

This study was approved by Kerman University of Medical Sciences, Ethics Committee (IR.KMU.REC.1398.721). 


\section{Study Design}

In this in-vitro study 3,4-dihydropyrimidin-2(1H)-ones was synthesis by nano-magnesium oxide and the antibacterial activity of flowable dental composites containing 0-5 wt\% 3,4-dihydropyrimidin-2(1H)-ones (it was weighed using a scale and added to the composite) was investigated by using agar diffusion and direct contact tests on the cured resins and also investigated of their mechanical, physical properties and water sorption of flowable dental composites.

\section{Preparation of High Surface Area Magnesium Oxide MgO}

The $\mathrm{Mg}(\mathrm{OH})_{2}$ (Fluka Chemical Corp., Ronkonkoma NY, USA) was rehydrated at $450^{\circ} \mathrm{C}$ for $2 \mathrm{~h}$ to obtain the catalyst that was used in this study. The maximum surface area of this catalyst $(\mathrm{MgO})$ was obtained after calcining at $400-500^{\circ} \mathrm{C}$.

\section{Preparation of Nanosized $\mathrm{MgO}$}

The $\mathrm{MgO}$ nanoparticles were produced by the precipitation of the magnesium hydroxide gels in an aqueous solution by using $\mathrm{Mg}\left(\mathrm{NO}_{3}\right)_{2}$ (Fluka Chemical Corp., Ronkonkoma NY, USA) and liquid ammonia as the precipitating agent. Initially, the $\mathrm{pH}$ of $200 \mathrm{~mL}$ of distilled water was adjusted to 10.5 by adding liquid ammonia to this distilled water. A $0.1 \mathrm{M}$ magnesium nitrate solution was added dropwise to the solution. The salt solution was added at the rate of $20 \mathrm{~mL} / \mathrm{h}$. In addition, the $\mathrm{pH}$ of the mixture was maintained at $10.5 \mathrm{by}$ liquid ammonia solution. After completing the precipitation, the mixture was stirred at $25^{\circ} \mathrm{C}$ for $12 \mathrm{~h}$, filtered and washed with distilled water, finally dried at $120^{\circ} \mathrm{C}$, and calcined at $500^{\circ} \mathrm{C}$ for $2 \mathrm{~h}$.

Synthesis of 3,4-dihydropyrimidin-2(1H)-ones

Synthesis of 3,4-dihydropyrimidin-2(1H)-ones was performed by the reaction between benzaldehyde (Merck Chemical Co., Ltd., Shanghai, China) (2 mmol), urea (Merck Chemical Co., Ltd., Shanghai, China) (2 $\mathrm{mmol}$ ) and ethyl acetoacetate (Merck Chemical Co., Ltd., Shanghai, China) (2 mmol) in the presence of $\mathrm{MgO}$ (50 mg) in $\mathrm{CH}_{3} \mathrm{CN}$ (Merck Chemical Co., Ltd., Shanghai, China) (10 mL). The mixture was refluxed for $10 \mathrm{~min}$ [35]. This reaction is shown in Figure 1. After completion of the reaction, $\mathrm{MgO}$ was extracted by filtration and excess $\mathrm{CH}_{3} \mathrm{CN}$ was distilled off. The synthesized-white powder was recrystallized from $96 \%$ ethanol to achieve the pure product. The synthesis of this compound was confirmed by melting point (199-201) and FTIR test - FTIR 8300 Spectrophotometer (Shimadzu, Kyoto, Japan). FTIR spectrum is shown in Figure 2.

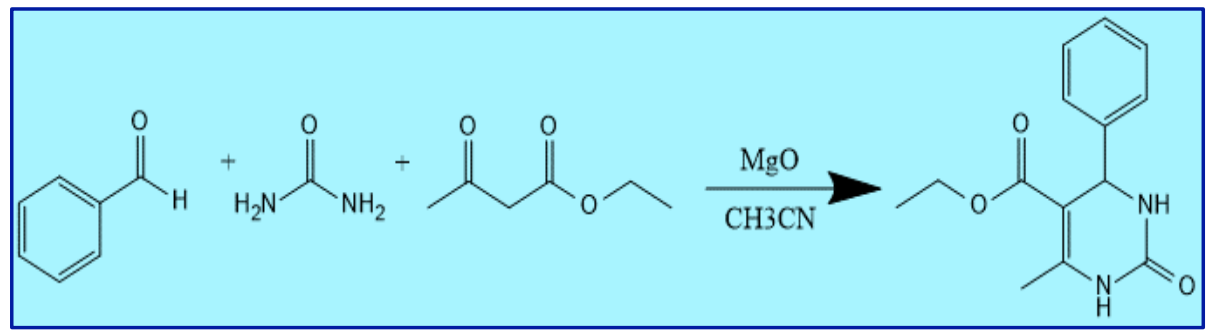

Figure 1. Synthesis of 3,4-dlhydropyrimidin-2(1H)-ones in the presence of nano-magnesium oxide.

Conditions of Bacterial Growth

Streptococcus mutans PTCC 1683 (Persian Type Culture Collection, IROST, Iran) were applied in this research. The bacteria were cultured aerobically overnight in $5 \mathrm{ml}$ of brain-heart infusion (High Media, India), at $37^{\circ} \mathrm{C}$. 


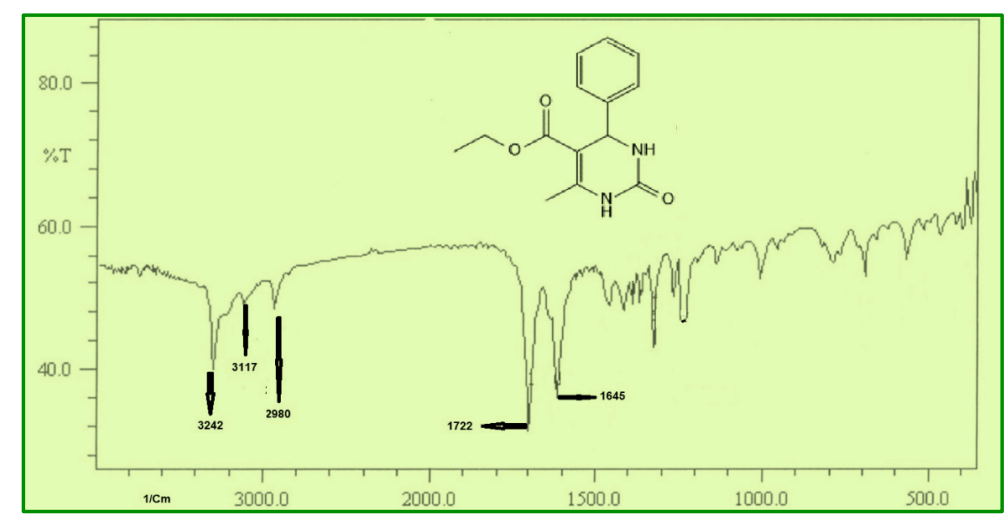

Figure 2. FTIR spectrum of 3,4-dihydropyrimidin-2(1H)-ones.

Preparation of Specimens

Six groups of specimen were prepared by mixing of 3,4-dihydropyrimidin-2(1H)-ones with resin composite (Tetric Flow - A2) (Ivoclar Vivadent Inc., Amherst, NY, USA) in 1,2,3,4 and 5 wt\% and o wt $\%$ as the control group. Mixing was performed in a dark room for $15 \mathrm{~min}$ and in room condition using a spatula. The sample size for the one-way ANOVA test was calculated by G*Power Software, version 3.1.9.4 (HeinrichHeine-Universität Düsseldorf, Düsseldorf, Germany). The significant level, power, and effect size were set to $0.05,80 \%$, and 0.7 . The sample size for each group was calculated at 6 . Therefore, we prepared 30 samples for each test.

\section{Direct Contact Test (DCT Test)}

This test was performed to investigate the antibacterial properties of the free surface of composites containing 3,4-dihydropyrimidin-2(1H)-ones. For this purpose, walls of $500 \mu \mathrm{l}$ microplates were covered by $200 \mu \mathrm{l}$ of un-polymerized resin. Then resin layers were polymerized by a light cure device for $40 \mathrm{~s}$. $10 \mu \mathrm{l}$ of the McFarland standard solutions of Streptococcus mutans $\left(3 \times 10^{8} \mathrm{CFU} / \mathrm{mL}\right.$, which contained $3 \times 10^{6}$ bacteria) were added to each microplate and samples were kept in $37^{\circ} \mathrm{C}$ for 1 hour. During this time (1 hour), bacteria were in direct contact with the resin surface and the solvent was evaporated after incubation. Then $300 \mu \mathrm{l}$ of $\mathrm{BHI}$ (brain-heart infusion medium) were added to each microplate. The lid of the containers were completely closed and samples were stored in $37^{\circ} \mathrm{C}$. In periods of $24,48,72,96$ and 120 hours, after this time, $50 \mu$ of the mixture (bacteria+BHI broth) was placed on culture medium and after 24 hours number of appeared bacteria colonies counted by using colony counter apparatus. This test was repeated 5 times for each test group (25 samples for each group 5 group in 5 times $(24,48,72,96$ and 120 hours) to ensure their accuracy [38,39]. The results were expressed as $\log _{10}(\mathrm{CFU})$.

\section{Flexural Strength Test}

Three-point bending strength was measured for specimens prepared from composites containing 3,4dihydropyrimidin-2(1H)-ones using the 4049 standard [40] by a testometric device (M350-10 CT, Rochdale, England). These samples were cured (LED, DEML, SDS Kerr, USA, with an intensity of circa $800 \mathrm{~mW} \mathrm{~cm}^{-2}$ ) in $25 \mathrm{~mm}$ x $2 \mathrm{~mm}$ molds between two sheets of polyester and flexural strength values were calculated from the following equation: $\mathrm{BS}=3 \mathrm{PL} / 2 \mathrm{BD} 2$, in which $\mathrm{P}$ is the load at the breaking point, $\mathrm{L}$ is the bearing spacing, $\mathrm{B}$ is the width and $\mathrm{D}$ is the sample thickness. In the bending test, the speed of the jaw was $0.5 \mathrm{~mm} / \mathrm{min}$ and the maximum load was $1 \mathrm{KN}$, and repeated for five times for each test group ( 5 samples for each group). 
Compressive Strength Test

The compressive strength test of composites containing 3,4-dihydropyrimidin-2(1H)-ones was measured [41]. The specimens in cylindrical molds with dimensions of $4 \mathrm{~mm}$ x $6 \mathrm{~mm}$ were cured and then were tested for compressive strength by a testometric device (M350-10 CT, Rochdale, England) and repeated for five times for each sample.

Determine Depth of Cure

To determine the depth of cure, the samples were transferred to steel molds of $4 \mathrm{~mm} \times 10 \mathrm{~mm}$ and polymerized by the light cure device in over of molds for 40 seconds. The composites were removed from the molds and separated uncured composite by using a spatula. The height of each cured sample was measured and divided by two to obtain the depth of the cure [42] and repeated five times for each test group ( 5 samples for each group).

\section{Water Sorption Test}

Samples were transferred to cylindrical molds with a diameter of $15 \mathrm{~mm}$ and a thickness of $1 \mathrm{~mm}$, cured according to ISO4049 [40]. The samples were transferred to an incubator at $37^{\circ} \mathrm{C}$ until their weight becomes fixed. Sample volume V $\left(\mathrm{mm}^{3}\right)$ was measured and then placed in $60 \mathrm{~mL}$ of distilled water at $37^{\circ} \mathrm{C}$ for one week. After this time, the samples were brought out from the water and the excess water was removed. The samples were weighted separately $(\mathrm{m} 2)$ and dried again, then reweighted (m3). Water sorption data were obtained from the following equation [43]: water sorption $=(\mathrm{m} 2-\mathrm{m} 3) / \mathrm{V}$.

These values were compared with the control composite samples and the water sorption test repeated five times for each test group ( 5 samples for each group).

\section{Data Analysis}

The data were analyzed by One-way ANOVA, and the Tukey post hoc HSD multiple comparison test. The level of significance was determined as $\mathrm{p}<0.01$.

\section{Results}

\section{Direct Contact Test (DCT)}

The results of bacterial colony count (Colony Forming Unit - CFU) are shown in Figure 3. It is clear that increasing of $\mathrm{w} \%$ of 3,4-dihydropyrimidin- $2(1 \mathrm{H})$-ones, antibacterial activity of composite increases significantly $(\mathrm{p}<0.001)$ and also time has a meaningful effect on antibacterial properties of resin.

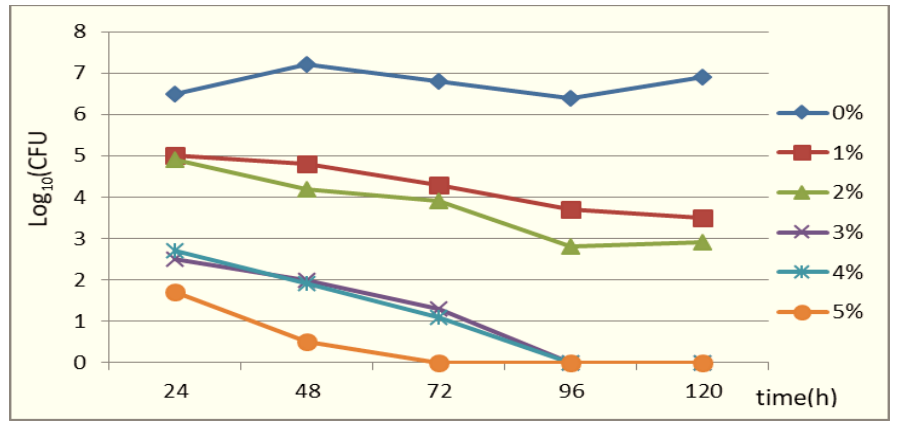

Figure 3. Colony forming unit following direct contact between $S$. mutans and resin composites containing 0-5 wt\% 3, 4-dlhydropyrimidin-2(1H)-ones. 
The mean of flexural strength results is presented in Table 1. As shown, with increasing 3,4dihydropyrimidin-2(1H)-ones until $3 \%$ in the composite, no significant difference was observed in flexural strength $(\mathrm{p}>0.001)$ and a significant decrease was observed in flexural strength with increasing 4 and $5 \%$ of the 3,4-dihydropyrimidin-2(1H)-ones in composite $(\mathrm{p}<0.001)$.

The mean of compressive strength results are shown in Table 1, and there is no significant difference between $0-4 \%$ groups $(\mathrm{p}>0.001)$, but there is a significant difference between $5 \%$ and other groups $(\mathrm{p}<0.001)$. Depth of cure results did not show any significant difference between the groups $(\mathrm{p}>0.001)$.

The mean of water sorption results is presented in Table 1. As we have shown, with increasing of 3,4dihydropyrimidin-2(1H)-ones in composite, the absorption of water decreases. However, this difference was not significant between groups $(\mathrm{p}>0.001)$.

Table 1. Flexural strength, compressive strength, depth of cure and water sorption (Mean and SD).

\begin{tabular}{|c|c|c|c|c|}
\hline Group & $\begin{array}{l}\text { Flexural Strength } \\
(\mathrm{MPa})^{2}\end{array}$ & $\begin{array}{c}\text { Compressive Strength } \\
(\mathrm{MPa})^{2}\end{array}$ & Depth of Cure $(\mathrm{mm})^{2}$ & $\begin{array}{l}\text { Water Sorption } \\
\left(\mu \mathrm{g} / \mathrm{mm}^{s}\right)^{2}\end{array}$ \\
\hline $0 \%$ & $97 \pm 5.04^{\mathrm{a}}$ & $149 \pm 8.04^{\mathrm{a}}$ & $2.5 \pm 0.012$ & $28 \pm 1.23$ \\
\hline $1 \%$ & $96 \pm 6.13^{\mathrm{a}}$ & $151 \pm 9.65^{\mathrm{a}}$ & $2.45 \pm 0.022$ & $27 \pm 1.75$ \\
\hline $2 \%$ & $94 \pm 5.06^{\mathrm{a}}$ & $138 \pm 14.04^{\mathrm{a}}$ & $2.35 \pm 0.012$ & $27 \pm 1.12$ \\
\hline $3 \%$ & $94 \pm 7.42^{\mathrm{a}}$ & $136 \pm 8.26^{\mathrm{a}}$ & $2.35 \pm 0.023$ & $26 \pm 1.75$ \\
\hline $4 \%$ & $62 \pm 5.23^{\mathrm{b}}$ & $136 \pm 12.32^{\mathrm{a}}$ & $2.5 \pm 0.032$ & $25 \pm 1.45$ \\
\hline $5 \%$ & $55 \pm 6.25^{\mathrm{c}}$ & $75 \pm 8.43^{b}$ & $2.32 \pm 0.015$ & $26 \pm 2.23$ \\
\hline p-value ${ }^{1}$ & $<0.001$ & $<0.001$ & 0.872 & 0.721 \\
\hline
\end{tabular}

${ }^{1}$ Calculated based on One-way ANOVA; ${ }^{2}$ Post hoc $=$ HSD multiple comparisons, the mean of groups with the same letter did not significantly differ at a $5 \%$ significance level.

\section{Discussion}

The agar diffusion test and the minimum inhibitory concentration are important traditional tests for evaluating and investigating of antibacterial properties and behavior of many pharmaceutical materials [44]. Agar diffusion test works based on solubility [45] of materials as tested material diffuses from the bulk surface and eliminates microorganisms. So this method cannot be used for materials with low solubility in water. One of the most important and necessary properties of proper dental material is low water solubility, so the agar diffusion test cannot be used here. It is not a suitable test method for dental material. On the other hand, DCT has very low sensitivity with solubility properties [34]. Knowing that it is an efficient method to evaluate antibacterial properties, we can investigate antibacterial properties in materials with very low water solubility.

Optical density absorbance or turbidity has been applied for the assessment of antibacterial particles. The turbidity evaluation, however, has a significant restriction as they consider both vital and dead bacteria in a liquid environment. This present research used the colony count method, and at the end of the mentioned time intervals, only the number of the live bacterial cells is ranked.

As shown in this research, the results indicated that 3,4-dihydropyrimidin-2(1H)-ones compound gives excellent antibacterial properties to the resin that increases with time and higher concentration. It should be noted that considering only antibacterial properties in composites is not efficient in dental restoration and should not reduce the dental material's physical and mechanical properties.

The depth of cure is commonly defined as the maximum thickness of the dental resin layer and it is applied to measure the best material characteristic throughout the depth of restoration [46]. Base on the depth of cure results in table1, the depth of cure values of the experimental groups are similar to that of the control group. It illustrates that all groups have an equivalent curing depth layer under a similar irradiation condition 
and also, according to water sorption values results in Table 1, the WS values of the experimental groups are similar to that of the control group.

Significant parameters to evaluate the longevity of dental materials are Mechanical properties and flexural strength and compressive strength are mostly used to evaluate the bending and compressive resistance of polymer materials, which could illustrate the resistance of deformation under external force. High FS and CS values show greater flexural capacities and rigidity of resin, which means that it could reduce the possibility of restoration defeat when the dental materials were subjected to masticatory load.

There is a lot of ISO to test the mechanical properties of a material. ISO4049 and 9917 are the common methods in dental materials and we have used these methods [47,48]. The antibacterial property of 3,4-dihydropyrimidin-2(1H)-ones reaches its maximum at $5 \% \mathrm{w}$ and after 72 hours, but it reduces the composites' compressive and flexural strength. According to our research, 3 is the best percentage of the 3,4dihydropyrimidin-2(1H)-ones to prevent the growth of Streptococcus mutans, and by increasing this amount of this compound, there was no significant decrease in the mechanical and physical properties of the composite. Low solubility 3-4-dlhydropyrimidin-2 $(1 \mathrm{H})$ in water makes it very suitable for use in the oral environment. Okeke et al. [49] used quaternary ammonium salts to create antibacterial properties in dental composites, but these compounds are highly soluble in water, and after a short time, the antibacterial properties of the composite disappear and the exit of this order from the composite leads to a reduction in the mechanical properties of the composite, but 3,4-dihydropyrimidin-2(1H)-ones is insoluble in water and eliminate this problem.

Yassei et al. [50] used copper oxide nanoparticles to create antibacterial properties in dental composites. Although this compound had an antibacterial effect in the composites, it reduced the depth of cure but used the 3,4-dihydropyrimidin-2 $(1 \mathrm{H})$-ones did not show a significant difference in depth of cure. In addition to the mentioned advantages, 3,4-dihydropyrimidin-2(1H)-ones is white and it has the same color as tooth enamel. So it can improve the antibacterial properties of the dental composites and at the same time preserving beauty characteristics of them. The next step in this study is to investigate the effect of this compound on its biocompatibility in the oral environment. We will do this research in the future.

\section{Conclusion}

Within the limitation of this study (we were unable to provide oral conditions), it can be concluded that the antibacterial property of 3, 4-dlhydropyrimidin-2(1H)-ones reach its maximum at $5 \%$ wt and after 72 hours but it reduces the compressive and flexural strength of the composites. According to our research, 3 is the best percentage of the 3, 4-dlhydropyrimidin-2(1H)- ones to prevent Streptococcus mutans' growth and by increasing this amount of this compound, there was no significant decrease in the mechanical and physical properties of the composite.

\section{Authors' Contributions}

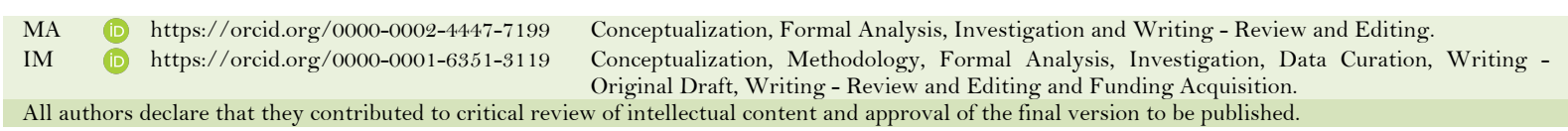

\section{Financial Support}

Kerman University of Medical Science (Grant No. 98000875). 


\section{Conflict of Interest}

The authors declare no conflicts of interest.

\section{Data Availability}

The data used to support the findings of this study can be made available upon request to the corresponding author.

\section{References}

[1] Kruzic JJ, Arsecularatne JA, Tanaka CB, Hoffman MJ, Cesar PF. Recent advances in understanding the fatigue and wear behavior of dental composites and ceramics. J Mech Behav Biomed Mater 2018; 88:504-33. https://doi.org/10.1016/j.jmbbm.2018.08.008

[2] Tanner J, Vallittu PK, Söderling E. Effect of water storage of E-glass fiber-reinforced composite on adhesion of Streptococcus mutans. Biomaterials 2001; 22(12):1613-8. https://doi.org/10.1016/s0142-9612(00)00314-8

[3] Tanner J, Carlén A, Söderling E, Vallittu PK. Adsorption of parotid saliva proteins and adhesion of Streptococcus mutans ATCC 21752 to dental fiber-reinforced composites. J Biomed Mater Res B Appl Biomater 2003; 66(1):391-8. https://doi.org/10.1002/jbm.b.10012

[4] Skjörland KK. Plaque accumulation on different dental filling materials. Scand J Dent Res 1973; 81(7):538-42. https://doi.org/10.1111/j.1600-0722.1973.tbo0362.x

[5] Skjorland KK. Bacterial accumulation on silicate and composite materials. J Biol Buccale 1976; 4(4):315-22.

[6] Tanner J, Robinson C, Söderling E, Vallittu P. Early plaque formation on fibre-reinforced composites in vivo. Clin Oral Investig 2005; 9(3):154-60. https://doi.org/10.1007/s00784-005-0317-4

[7] Mjör IA. The reasons for replacement and the age of failed restorations in general dental practice. Acta Odontol Scand 1997; 55(1):58-63. https://doi.org/10.3109/00016359709091943

[8] Burke F, Crisp RJ, Bell TJ, Healy A, Mark B, McBirnie R, et al. One-year retrospective clinical evaluation of hybrid composite restorations placed in United Kingdom general practices. Quintessence Int 2001; 32(4):293-8.

[9] Zhu W, Lao C, Luo S, Liu F, Huang Q, He J, et al. Mechanical and antibacterial properties of benzothiazole-based dental resin materials. J Biomater Sci Polym Ed 2018; 29(6):635-45. https://doi.org/10.1080/09205063.2018.1429861

[10] Makvandi P, Jamaledin R, Jabbari M, Nikfarjam N, Borzacchiello AJDM. Antibacterial quaternary ammonium compounds in dental materials: a systematic review. Dent Mater 2018; 34(6):851-67. https://doi.org/10.1016/j.dental.2018.03.014

[11] Wiegand A, Buchalla W, Attin T. Review on fluoride-releasing restorative materials - fluoride release and uptake characteristics, antibacterial activity and influence on caries formation. Dent mater 2007; 23(3):343-62. https://doi.org/10.1016/j.dental.2006.01.022

[12] Leung D, Spratt DA, Pratten J, Gulabivala K, Mordan NJ, Young AM. Chlorhexidine-releasing methacrylate dental composite materials. Biomaterials 2005; 26(34):7145-53. https://doi.org/10.1016/j.biomaterials.2005.05.014

[13] Burke F, Ray N, McConnell R. Fluoride-containing restorative materials. Int Dent J 2006; 56(1):33-43. https://doi.org/10.1111/j.1875-595x.2006.tboo072.x

[14] Amaral G, Negrini T, Maltz M, Arthur RA. Restorative materials containing antimicrobial agents: is there evidence for their antimicrobial and anticaries effects? A systematic review. Aust Dent J 2016; 61(1):6-15. https://doi.org/10.1111/adj.12338

[15] Jedrychowski JR, Caputo AA, Kerper S. Antibacterial and mechanical properties of restorative materials combined with chlorhexidines. J Oral Rehabil 1983; 10(5):373-81. https://doi.org/10.1111/j.1365-2842.1983.tbo0133.x

[16] Niu L, Fang M, Jiao K, Tang L, Xiao Y, Shen L, et al. Tetrapod-like zinc oxide whisker enhancement of resin composite. J Dent Res 2010; 89(7):746-50. https://doi.org/10.1177/0022034510366682

[17] Hojati ST, Alaghemand H, Hamze F, Babaki FA, Rajab-Nia R, Rezvani MB, et al. Antibacterial, physical and mechanical properties of flowable resin composites containing zinc oxide nanoparticles. Dent Mater 2013; 29(5):495505. https://doi.org/10.1016/j.dental.2013.03.011

[18] Cheng L, Weir MD, Xu HH, Antonucci JM, Lin NJ, Lin-Gibson S, et al. Effect of amorphous calcium phosphate and silver nanocomposites on dental plaque microcosm biofilms. J Biomed Mater Res B Appl Biomater 2012; 100(5):137886. https://doi.org/10.1002/jbm.b.32709

[19] Hernández-Sierra JF, Ruiz F, Pena DCC, Martínez-Gutiérrez F, Martínez AE, Guillén AdJP, et al. The antimicrobial sensitivity of Streptococcus mutans to nanoparticles of silver, zinc oxide, and gold. Nanomedicine 2008; 4(3):237-40. https://doi.org/10.1016/j.nano.2008.04.005

[20] Burne RA. Oral streptococci... products of their environment. J Dent Res 1998; 77(3):445-52. https://doi.org/10.1177/00220345980770030301

[21] Szczepańska J, Lubowiecka-Gontarek B, Pawłowska E, Szydłowska-Walendowska B. Czynniki ryzyka próchnicy związane z żywieniem a liczebność bakterii próchnicotwórczych w ślinie dzieci w wieku 3 lat. Dent Med Probems 2008; 45(2):156-64. [In Polish]. 
[22] Stańczak D, Sionek MS, Nodzak AR, Osowiecki H. Zastosowanie testu bakteryjnego w celu określenia ryzyka próchnicy u dzieci do trzeciego roku życia. Dent Med Probl 2003; 4O(2):273-79. [In Polish].

[23] Manowiec J, Lisiecka K, Suszczewicz A. Wpływ programu profilaktycznego realizowanego u dzieci przedszkolnych na liczbę Streptococcus mutans i Lactobacillus w ślinie. Dent Med Probl 2003; 4O(2):281-6. [In Polish].

[24] Hussain MS, Wafaa S, Altamemi SJDIT. Antibacterial activity of pomegranate peels aqueous extractions on dental caries and gingivitis Streptococcus mutans in compared with $0.2 \%$ chlorhexidine. Drug Invent Today 2019; 11(12):3097-3100.

[25] An S, Evans JL, Hamlet S, Love RM. Incorporation of antimicrobial agents in denture base resin: A systematic review. J Prosthet Dent 2020; So022-3913(20):30251-1. https://doi.org/10.1016/j.prosdent.2020.03.033

[26] Kale P. Synthesis, Characterization and Biological Evaluation of Some Novel Fused Pyrimidine and Oxazine Heterocycles. [Thesis]. Swami Ramanand Teerth Marathwada University: Maharashtra, India. 2019.

[27] Jarallah SA, Nief OA, Atia AJK. Synthesis, characterization of heterocyclic compounds and preliminary evaluation of their antibacterial activity and antioxidant agents. J Pharm Sci Res 2019; 11(3):1010-5.

[28] Mohammadzadeh I, Asadipour A, Pardakhty A, Abaszadeh M. New crown ether-based ionic liquids as a green and versatile organocatalyst for three-component synthesis of 1, 5-Dihydropyrano [2, 3-c] chromene derivatives. Lett Org Chem 2020; 17(3):240-5.

[29] Asif M. A mini review: biological significances of nitrogen hetero atom containing heterocyclic compounds. Bioorg Chem 2017; 2(3):146-52.

[30] Ab Kadhem S, Ali SM, Atia AJK, Salih RH, Abdulrazaq RA. Synthesis and study of biological activities of compounds derived from new Imidazole derivative. J Pharm Sci Res 2018; 10(11):2818-24.

[31] Fang Z, Zheng S, Chan K-F, Yuan W, Guo Q, Wu W, et al. Design, synthesis and antibacterial evaluation of 2, 4disubstituted-6-thiophenyl-pyrimidines. Eur J Med Chem 2019; 161:141-53. https://doi.org/10.1016/j.ejmech.2018.10.039

[32] Maddila S, Gorle S, Seshadri N, Lavanya P, Jonnalagadda SB. Synthesis, antibacterial and antifungal activity of novel benzothiazole pyrimidine derivatives. Arab J Chem 2016; 9(5):681-7. https://doi.org/10.1016/j.arabjc.2013.04.003

[33] Tale RH, Rodge AH, Hatnapure GD, Keche AP. The novel 3, 4-dihydropyrimidin-2 (1H)-one urea derivatives of Naryl urea: synthesis, anti-inflammatory, antibacterial and antifungal activity evaluation. Bioorg Med Chem Lett 2011; $21(15): 4648-51$. https://doi.org/10.1016/j.bmcl.2011.03.062

[34] Eskandarizadeh A, Mohammadzadeh I, Shahravan A, Bavafa M, Kakooei S, Torabi MJDRJ. Prevention of secondary caries by a new antibacterial compound. Dent Res J 2020; 17(1):40-7.

[35] Ranjbar M, Dehghan Noudeh G, Hashemipour M-A, Mohamadzadeh I. A systematic study and effect of PLA/Al2O3 nanoscaffolds as dental resins: mechanochemical properties. Artif Cells Nanomed Biotechnol 2019; 47(1):201-9. https://doi.org/10.1080/21691401.2018

[36] Afshar MK, Torabi M, Bahremand M, Afshar MK, Najmi F, Mohammadzadeh I. Oral health literacy and related factors among pregnant women referring to health government institute in Kerman, Iran. Pesqui Bras Odontopediatria Clín Integr 2020; 20:5337. https://doi.org/10.1590/pboci.2020.011

[37] Mohammadzadeh I, Bavafa M, Sheibani HJRRC. A fast one-pot multi-component synthesis of 3, 4-dihydropyrimidin$2(1 \mathrm{~h})$-ones in the presence of magnesium oxide as a highly effective heterogeneous base catalyst. Rev Roum Chim 2013; 58(9-10):773-7.

[38] Weiss E, Shalhav M, Fuss Z. Assessment of antibacterial activity of endodontic sealers by a direct contact test. Endod Dent Traumatol 1996; 12(4):179-84. https://doi.org/10.1111/j.1600-9657.1996.tbo0511.x

[39] Beyth N, Domb AJ, Weiss EI. An in vitro quantitative antibacterial analysis of amalgam and composite resins. J Dent 2007; 35(3):201-6. https://doi.org/10.1016/j.jdent.2006.07.009

[40] International Organization for Standardization. ISO 4049:2009 Dentistry - Polymer-based restorative materials. Geneva: International Organization for Standardization; 2009.

[41] International Organization for Standardization. ISO 9917-1: Dentistry - Waterbased cements - Part 1: Powder/liquid acid-base cements. Geneva: International Organization for Standardization; 2007.

[42] Hojati ST, Alaghemand H, Hamze F, Babaki FA, Rajab-Nia R, Rezvani MB, et al. Antibacterial, physical and mechanical properties of flowable resin composites containing zinc oxide nanoparticles. Dent Mater 2013; 29(5):495505. https://doi.org/10.1016/j.dental.2013.03.011

[43] Munhoz T, Fredholm Y, Rivory P, Balvay S, Hartmann D, da Silva P, et al. Effect of nanoclay addition on physical, chemical, optical and biological properties of experimental dental resin composites. Dent Mater 2017; 33(3):271-9. https://doi.org/10.1016/j.dental.2016.11.016

[44] Boss J, Dance DA, Chanthongthip A, Newton PN, Wuthiekanun V, Robinson MT. Antimicrobial susceptibility testing of Leptospira spp. in the Lao People's Democratic Republic using disk diffusion. Am J Trop Med Hyg 2019; 100(5):1073-8. https://doi.org/10.4269/ajtmh.18-0955

[45] Lewinstein I, Matalon S, Slutzkey S, Weiss EI. Antibacterial properties of aged dental cements evaluated by directcontact and agar diffusion tests. J Prosthet Den 2005; 93(4):364-71. https://doi.org/10.1016/j.prosdent.2005.01.008 
[46] Hughes K, Powell K, Hill A, Tantbirojn D, Versluis A. Delayed photoactivation of dual-cure composites: effect on cuspal flexure, depth-of-cure, and mechanical properties. Oper Dent 2019; 44(2):E97-E104. https://doi.org/10.2341/18-140-L

[47] Stencel R, Pakieła W, Barszczewska-Rybarek I, Żmudzki J, Kasperski J, Chladek G, et al. Effects of different inorganic fillers on mechanical properties and degree of conversion of dental resin composites. Arch Metall Mater 2018; 63(3):1361-9. https://doi.org/10.24425/123813

[48] Yadav S, Gangwar S. The effectiveness of functionalized nano-hydroxyapatite filler on the physical and mechanical properties of novel dental restorative composite. Int J Polym Mater 2019; 69(14):1-12. https://doi.org/10.1080/00914037.2019.1631822

[49] Okeke UC, Snyder CR, Frukhtbeyn SA. Synthesis, purification and characterization of polymerizable multifunctional quaternary ammonium compounds. Molecules 2019; 24(8):1464. https://doi.org/10.3390/molecules24081464

[50] Yassaei S, Nasr A, Zandi H, Motallaei MN. Comparison of antibacterial effects of orthodontic composites containing different nanoparticles on Streptococcus mutans at different times. Dental Press J Orthod 2020; 25(2):52-60. https://doi.org/10.1590/2177-6709.25.2.052-060.oar 